\title{
Leadership for Equity and Social Justice in Arab And Jewish Schools in Israel: Leadership Trajectories and Pedagogical Praxis
}

\author{
Khalid Husny Arar \\ The Center for Academic Studies \& Sakhnin College \\ Israel
}

\begin{abstract}
The research investigated how principals in Israel's Jewish and Arab school systems perceive and practice their role in promoting equitable education to bridge socio-economic and pedagogic gaps. It asked how Jewish and Arab principals understand the concept of social justice and what they do in order to promote social justice reality in their schools. Semi-structured interviews were conducted with $10 \mathrm{Arab}$ and Jewish principals. Analysis of interviews indicated that Israeli education policy perpetuates ethnic and social gaps. The principals reported different personal trajectories that shaped their perceptions of social and described strategies used to promote social justice.
\end{abstract}

KEYWORDS: principal, Arab, Jewish, Israel, social justice

\author{
School Leadership and Social Justice Discourse \\ The Israeli Education System \\ Methodology \\ Findings \\ Discussion and Conclusion \\ References \\ Author Contact
}

Increased interest in the concept of social justice (SJ) in educational research reflects the aspiration to implement principles of $\mathrm{SJ}$ in schools (Lindsey \& Lindsey, 2011; Berkovich, 2014; Stevenson, 2007; Theoharis \& Brooks, 2013). Yet, in the main, this aspiration remains largely rhetorical, often failing to inform school practice (Blankstein \& Houston, 2011; North, 2008). The implementation of SJ policy and practice to correct injustice, discrimination, and exclusion remains elusive, politically loaded, and subject to numerous interpretations (Jean-Marie, Normore, \& Brooks, 2009).

North (2008) indicated that schools are challenged by society's inequalities to become sites of justice, inclusion, and caring. In order to meet these expectations and create sites that meet these goals, SJ leaders should "develop a heightened and critical awareness of oppression, exclusion, and 
marginalization" (Brooks \& Miles, 2006, p. 5), analyzing how institutional power arrangements and practices favor some groups over others (Diem \& Boske, 2012). Other scholars have investigated how educational leaders can implement SJ policy and praxis in schools (e.g., Ayers, Quinn, \& Stovall, 2009; Berkovich, 2014; Bogotch \& Shields, 2014; Brooks \& Miles, 2006; Jean-Marie et al., 2009). These scholars indicated that SJ policy should include distributive justice, associational justice, and cultural justice. Diem and Boske (2012) clarify that SJ leaders should be aware of the power arrangement in an organization and of practices intended to maintain social status, to appropriate positions, and to establish conservative organizational procedures. This sensitive and skilled analysis can help them to design and create long-term changes at different social levels to enhance equality of opportunity and create room for initiative (Berkovich, 2014). The actions of SJ leadership are influenced by, and influence, the social context in which they operate. Therefore, I now describe the backdrop to this research, the characteristics and social structure of Israeli society, with special consideration of relations between the two major ethnic groups, Jews and Arabs.

When Israel was established in part of the former British Mandate of Palestine territory in 1948, the Arab population that remained within the new state's borders numbered a mere 156,000, weakened and depleted by war and the loss of its elite due to expulsion or flight. Together with the Jewish population residing in this area, they became citizens of the new state. This article relates only to the Jewish and Palestinian citizens of the State of Israel (it does not consider the Palestinians living in Palestinian territories in the West Bank or Gaza). The Jewish majority population and the indigenous Palestinian Arab minority population of Israel mostly live in separate geographical localities, apart from a handful of multicultural towns.

Despite the fact that both the Jewish and Arab societies in Israel contain multiple religious sects and sub-cultures, it has been noted that Arab society is mainly a traditional-patriarchal, male-dominated, and less egalitarian culture, characterized by a collectivist culture (Abu Baker, 2008), while Jewish society is in general a more individualist and egalitarian culture (Sagie, Kantor, Elizur \& Barhoum, 2005). This generalization is further qualified because some scholars discern a process of modernization in Arab society partly due to contact with Jewish society and partly due to the influence of mass media (Arar, 2014a). Arab citizens do not enjoy full equal civilian rights and face obstacles in attaining access to public resources, and the Palestinian nation is still embroiled in conflict with the Jewish state in which Palestinian citizens of Israel live. Politically underrepresented in government, they have difficulties integrating within Israel's employment market. Consequently, $53 \%$ of the Arab population in Israel lives below the poverty line (Ben-David, 2014; Gara, 2013).

Arab and Jewish education are separate with unequal resources, allocations and outputs. Arab education is subordinate to government control of education contents and organizational structure (Arar \& Abu-Asbah, 2013; Golan-Agnon, 2006). The curriculum (content) of state schools is $75 \%$ state- 
mandate. Government-dictated content in the standard learning programmes almost completely ignores the narratives of the Arab nation and the Palestinians living in Israel. Additionally, outputs of the two education systems are unequal. Recent statistics show that $53 \%$ of Jewish students were eligible for matriculation in comparison to $32.4 \%$ of Arab students (Sbirsky \& Degan-Bouzaglo, 2009).

Since equity and SJ are contextually constructed, it is instructive to learn about educational leadership perceptions and daily praxis promoting equity as they are expressed in Israel, a multi-ethnic state with a marginalized indigenous national minority. This paper investigates how school principals in Israel's Jewish and Arab school systems perceive and practice their role as those who can promote equitable education to bridge socio-economic and pedagogic gaps. More specifically, the paper posed the following research questions:

1. How do Jewish and Arab principals understand the concept of SJ?

2. What do they do in order to promote SJ reality in their schools?

To respond to these questions, qualitative methodology was employed, using semi-structured in-depth interviews to elicit the views and practices of 10 Jewish and Arab principals.

The paper begins with a review of literature relating to educational leadership for SJ and the way in which this is expressed in Israel, comparing the Jewish and Arab divisions of the Israeli education system. It then presents main findings from the interviews with the principals. The paper closes with conclusions concerning the principals' perceptions of $\mathrm{SJ}$ and the implementation of principles of SJ in the schools of the dominant majority group and those of the minority group.

\section{School Leadership and SJ Discourse}

The school can play a significant role in leading social change, especially in light of persistent social and academic gaps in society (Jean-Marie et al., 2009; Oplatka \& Arar, 2014). Social Justice (SJ) is defined as "a perception that believes in the responsibility of a society and its institutions to promote economic welfare for all its members" (Mansfield, 2013, p. 647). In order to maximize the effectiveness of this role for the amelioration of inequality, it is important to study and improve implementation of $\mathrm{SJ}$ in schools.

A society committed to SJ should ensure that every child experiences optimal levels of wellbeing, irrespective of ethnic origin and social background (Bogotch \& Shields, 2014). Scholars indicate that the implementation of SJ in education "necessitates an egalitarian approach to educational processes, even if the results are not equal" (Brooks \& Miles, 2006, p.9). However, SJ is interpreted differently in different contexts (Berkovich, 2014; Furman, 2012).

Research shows that a school leader's ability to introduce educational equality, improve access, and produce superior educational achievements is 
linked with that leader's ability to develop a school culture promoting values of egalitarianism, respecting diversity, and helping students to realize their personal potential (Brooks \& Miles, 2006; Dantley \& Tillman, 2010; Theoharis, 2009). If public education aims to produce "full and equal participation of the population in educational resources," then resources should be distributed in an equal manner, students should receive physical and mental security, and the school should become a place that allows equal, empowering, and fulfilling development of personal potential (Shoho, 2006). This means that "the main effort of the school leaders should be invested in the transformation of the school culture to a more democratic, participatory and containing society" (Mansfield, 2013, p. 646), helping to arouse consciousness of inequality, exclusion and suppression (Berkovich, 2014). According to Rodriguez and Bauman (2005), this is possible if school leaders "develop the ability for critical analysis of the socio-economic status of their students and of the school community." Then, together with the school community, efforts should be made to identify how these basic data influence perceptions and attitudes concerning teaching-learning, and how these data position some of the students on scales of poverty and exclusion (p.138).

The literature identifies certain characteristics of leaders who cope with the challenge of inequality and gaps in education (Berkovich, 2014; Bogotch \& Shields, 2014; Brooks \& Miles, 2006; Stevenson, 2007). According to Brooks, Jean-Marie, Normore, and Hodgis (2007), leadership for SJ is based on critical consciousness, compassion, democratic principles, psychological containment, liberation, and action for change; these leaders feel that they have a mission to fulfill a moral code and to correct society. They prevent negative influences in the school and provide opportunities for success and the realization of dreams (Nino, 2014). Identifying the core requirements for school leadership for SJ, Theoharis (2009) asserted that school leaders must (a) acquire a broad, re-conceptualized consciousness/knowledge/skill base; (b) possess core leadership traits; (c) advance inclusion, access, and opportunity for all; (d) improve the core learning context, both the teaching and curriculum; (e) create a climate of belonging; (f) raise student achievement; and (g) sustain themselves professionally and personally.

Other scholars have pointed out that educational leaders identified with SJ usually learned about it and experienced the need for it first hand during their childhood, undergoing experiences of exclusion and suffering in a discriminatory reality. These leaders strive daily to enable students to experience holistic development accompanied by adult concern and compassion (Bogotch \& Shields, 2014; Sanders-Lawson, Smith-Campbell \& Benham, 2009).

To sum up, the moral responsibility of educational leaders is especially important in light of the numerous social problems that marginalized groups and minorities face because of discrimination and/or lack of resources. SJ leadership has a magnified significance in a social context where there is inequity and injustice, since it allows moral responsibility to be instilled in schools and can alter both privileged and underprivileged students' perceptions of their reality, giving them hope and showing them how to implement principles of SJ. 
Education is, however, an open system embedded in a complex social context. Educational leaders are continually urged to examine how educational problems are formed in a broad social context (Adams \& Copeland, 2005; Berkovich, 2014) in order to be able to counteract these processes in their work in schools.

I now describe the research setting in the Israeli education system and the particular factors influencing social justice in this system.

\section{The Israeli Education System: A Socio-ethnic and Educational Perspective}

Sixty years after the establishment of the State of Israel, the indigenous Arab minority has multiplied 10 times and, according to Israel's Central Bureau of Statistics (2013), numbered 1,658,000 persons in 2013, representing $20.7 \%$ of the country's population (including $82.1 \%$ Muslims, 9.4\% Christians and $8.4 \%$ Druze). The Arab population of Israel contends with a constant identity conflict as citizens of a state that is officially defined as a Jewish state. Most identify themselves as Palestinians, yet they are citizens of a country that is in conflict with members of its own people, the Palestinian people in neighboring states (Nakhleh, 1979). These and other attributes complicate the identity of this national minority. Thus, the collective identity of the Arab community in Israel comprises several elements: citizenship (Israeli), nationality (Palestinian), ethnicity (Arab), and religion (Islamic or Christian or Druze). Arab citizens of Israel see their identity as comprised primarily of a mix of these four elements, as a delicate balance among them, or as one identity displacing another (Smooha, 2002). This ongoing identity crisis alters with changing circumstances (Diab \& Mi'ari, 2007), evoking multi-layered discourse relating to issues such as ethnic democracy (Smooha, 2002), "multiculturalism" (Yona \& Shenhav, 2005), "Palestinian indigenousness," and Israel as an "ethnocracy" (Yiftachel \& Ghanem, 2004). Many Arab citizens of Israel share the belief that the development of Palestinian society in Israel is not a natural development, but rather the reaction to a continuous state of crisis (Ghanem \& Rouhana, 2001).

Politically, the Arab minority has not managed to turn their demographic proportion into political power; economically, the average living standard of the Arab population is $60 \%$ less than that of the Jewish population (Gara, 2013), and the average Arab man's income is approximately half the average Jewish man's income. Vocationally, Arabs find it difficult to enter the Israeli job market and constitute only $6 \%$ of civil service (Arlosoroff, 2014).

The Jewish majority community has grown in similar proportions from approximately 650,000 in 1948 to $6,135,000$ (75\% of Israel's population) in 2013 (Central Bureau of Statistics, 2013). The Jewish population includes many ethnic and religious sub-cultures. Personal and group identity is formed by extent of identification with the Jewish religion, ethnic sub-groups (Ashkenazi and Sephardi origin), and Israeli nationality. This is largely an urban population, and 
includes all socio-economic strata. Though average income per family is significantly higher for Jewish families than the average for Arab families, the gap between the wealthy and poor Jews has reached worrying proportions and generated protest and demonstrations in recent years. In 2011, Israel was ranked fifth in unequal income distribution among the 34 OECD countries (Association for Civil Rights in Israel, 2011; Ben-David, 2014).

Education in Israel is segregated, with separate educational sectors for religious and secular Jewish children and for Arab children, while each sector includes both state and non-state schools. The language of studies for Jewish children is Hebrew, and for Arab children, Arabic. Because of the segregation, the likelihood of encounters between Jewish and Arab children is very low (Gibton, 2011; Golan-Agnon, 2006).

Since the separate Arab and Jewish education systems receive different government budgets, to the detriment of the Arab education system, it seems that there is a lack of distributive justice in the Israeli education system (Arar \& Abu-Asbah, 2013). For example, the Arab education system budget is approximately $30 \%$ less that the Jewish education system budget, relative to the size of the two populations (Arlosoroff, 2014). This budgetary gap appears to affect outputs of the two education systems so that Arab students have lower achievements in both national and international standard exams. Balas and Adler (2009) reported significant gaps between the Jewish and Arab education systems, noting especially the larger amount of lesson hours assigned to the Jewish system, a far larger proportion of Jews studying 13 years or more, a decrease in the average years of education among the Arab public from 19992009, higher dropout rates for Arab students from the school system, lower achievements by Arab students in standard national exams in elementary education and an under-representative proportion of Arab university students and faculty staff. This unequal reality offers a serious challenge for educational leaders interested in introducing SJ (Arar, 2014b). The gaps between Jewish and Arab education are illustrated in Table 1.

Despite a steady increase in the proportions of young people studying in Arab schools in Israel since 1948, for many years the Arab education system has failed to achieve desired academic results. Arab students' achievements are $28.5 \%$ lower in Grade 4, and 29\% lower in Grade 8. Among Jewish students, $50.5 \%$ are eligible for matriculation in comparison to a stagnant $32.4 \%$ among Arab students (2008-2009). The gap continues to grow in higher education. In 2008 , only $11.8 \%$ of Arab high school graduates were accepted to higher education, and their achievements in B.A. studies were $78.2 \%$ lower than those of Jewish students (Sbirsky \& Degan-Bouzaglo, 2009). 
Table 1

The consequences of Israeli government policies: Gaps between Jewish and Arab education from nursery to university, 2008-2010

\begin{tabular}{|c|c|c|c|}
\hline \multicolumn{2}{|l|}{ Aspect compared } & $\begin{array}{c}\text { Jewish } \\
\text { population }\end{array}$ & $\begin{array}{c}\text { Arab } \\
\text { population }\end{array}$ \\
\hline \multicolumn{2}{|l|}{$\begin{array}{l}\text { Number of persons under the age of } 17 \\
\text { (Statistics for 2009) }\end{array}$} & 1,699, 273 & 678,000 \\
\hline \multicolumn{2}{|c|}{$\begin{array}{l}\text { Percentage of infants registered in pre-school at } \\
\text { age } 2\end{array}$} & $61.3 \%$ & $13.7 \%$ \\
\hline \multicolumn{2}{|c|}{$\begin{array}{l}\text { Percentage of infants registered in nursery at } \\
\text { age } 5\end{array}$} & $97.5 \%$ & $94.5 \%$ \\
\hline \multicolumn{2}{|c|}{$\begin{array}{l}\text { Average number of pupils in primary school } \\
\text { class }\end{array}$} & 24.54 & 28.81 \\
\hline \multicolumn{2}{|c|}{$\begin{array}{l}\text { Percentage of school dropout from Year } 9 \text { to } \\
\text { Year } 12\end{array}$} & $13.5 \%$ & $21.3 \%$ \\
\hline \multicolumn{2}{|c|}{$\begin{array}{l}\text { Percentage of pupils eligible for matriculation } \\
\text { certificates (suitable for university entrance } \\
\text { threshold requirements) }\end{array}$} & $75.9 \%$ & $30.8 \%$ \\
\hline \multirow{2}{*}{$\begin{array}{l}\text { Average score for Psychometric } \\
\text { Test: also needed for } \\
\text { University entrance (maximum } \\
\text { score }=800 \text { ) }\end{array}$} & Males & 585 & 479 \\
\hline & Females & 548 & 445 \\
\hline \multicolumn{2}{|c|}{$\begin{array}{l}\text { Percentage of applicants for university, rejected } \\
\text { for first year of academic studies for a first } \\
\text { degree }\end{array}$} & $21.9 \%$ & $38 \%$ \\
\hline \multirow{3}{*}{$\begin{array}{l}\text { Percentage of those graduating with } \\
\text { a degree (all tertiary education } \\
\text { institutes: university, academic } \\
\text { colleges, teacher training colleges) }\end{array}$} & $\begin{array}{l}1^{\text {st }} \\
\text { degree }\end{array}$ & $87.6 \%$ & $10.3 \%$ \\
\hline & $\begin{array}{l}2^{\text {nd }} \\
\text { degree }\end{array}$ & $93.5 \%$ & $4.9 \%$ \\
\hline & $\begin{array}{l}3^{\text {rd }} \\
\text { degree }\end{array}$ & $94.5 \%$ & $2.8 \%$ \\
\hline
\end{tabular}

Source: Jabareen and Agbariah (2010)

Since there are limited career opportunities for educated Arabs in Israel, the role of school principal is considered one of the most desirable senior positions in Arab society and tenders for this post often provoke intense power struggles (Arar \& Abu-Rabia-Queder, 2011). Additionally, Israel's Arab society is still predominantly a traditional patriarchal society; so, while most principals and deputies in the Jewish education system are women, in Israel's Arab education system men usually hold these positions, reflecting cultural norms that limit women's advancement in the public sphere. This fact influences the perception of the role and its performance in Arab schools. Arab schools are largely administered in what is considered as a masculine management style, 
emphasizing authoritarian administration and a strict hierarchy of command (Hofstede, 2001; Cubillo \& Brown, 2003; Arar, Shapira, Azaiza, \& HertzLazrowitz, 2013), and there is no tradition of distributed leadership. However, some women have managed to attain leadership roles in Arab schools and introduce a more feminine style of administration, more participatory with greater care and concern (Arar et al. 2013; Noddings, 2003). A recent Israeli Education Ministry reform, entitled "New Horizons," places increased emphasis on teacher evaluation, and principals have been trained to become professional evaluators (Arar, 2014b).

In a country split by political and religious conflicts, school principals can play an influential role in improving co-existence and preparing students to accept and benefit from diversity. The school can also provide democratic experiences to prepare students for their future participation as adults in society's democratic processes. Several levels and issues of SJ challenge the staff of Israel's schools. Although Jewish and Arab school principals undergo similar training for their management role in the Avney Rosha Institute for Educational Leadership and share a similar role definition (Avney Rosha, 2009), they cope with different problems in the field. Between the two education systems, there is a clear need for initiatives to enable discourse between Jewish-Arab students. Within the Jewish education system, SJ relates to the integration of students from weaker socio-economic strata or immigrants from the USSR and Ethiopia (Shavi, Weinstein, Stone, \& Bodam (2013), while in the Arab education system SJ relates to efforts to ameliorate effects of the inferior budgeting for the Arab school system. Arab schools also relate to discourse between Druze, Muslim, and Christian students and with students from border regions or from the West Bank under the Palestinian authority or from Gaza and cope with the challenge of providing equal gender access to educational resources overshadowed by a culture that often discriminates against women. Additionally $\mathrm{SJ}$ in schools relates to the intrusion of external political pressures (such as the government dictation of content, or the influence of local "hamulla" politics on school culture) (Oplatka \& Arar, 2014). The present study aimed to understand how principals in both branches of the Israeli education system, Arab and Jewish, view their roles as potential leaders for social justice and what they do in practice to realize these roles.

\section{Methodology}

A comparative qualitative multiple case study was used for empirical data collection and analysis (Thomas, 2011). To select an appropriate research sample, I applied my familiarity with many school principals as the chairperson of the Department of Educational Leadership and Management and consulted Ministry of Education supervisors who recommended the participants as principals who had "turned their schools around." In all, I approached 16 principals, who I found complied with the description by Theoharis (2009) of SJ 
leaders in terms of perceptions, traits, and education praxis. Two other criteria determined the participants' selection: (a) their willingness to participate in a longterm interview that could take time, and (b) the sample's ability to represent both the Jewish and Arab state education systems, in both rural and urban areas. Ten of those I approached (five Jewish principals and five Arab principals) agreed to participate in an in-depth semi-structured interview (Creswell, 2007) and these became the research participants. Each principal represented a separate case study.

In-depth semi-structured narrative interviews were conducted with each principal. All participants were individually interviewed for about two hours in the schools' offices. The interviews with the Jewish principals were conducted in Hebrew and those with the Arab principals in Arabic (both of which I speak fluently at the level of mother-tongue).

The objective of the study was explained, and anonymity was promised. Participation was consensual; the principals were able to terminate the interview at will. The interviews began with the reading of a vignette illustrating socioeconomic diversity in school; then the principal was asked to describe his/her perspectives concerning national, gender, or social status discrimination, indicating the sources of their SJ perception and their action to promote SJ and equity in the school (Brooks \& Miles, 2006, p. 5). This was followed by clarifying questions regarding the interviewee's description such as, "Can you expand slightly on this matter" and interpretative questions such as "If I have understood you correctly, in your view, SJ praxis is ...".

\section{Research Participants}

The research population included 10 school principals (five females and five males), five from Jewish schools and five from Arab schools including state elementary and junior-high schools, in Northern and Central Israel, who consented to participate in the study.

Table 2

Research participants by age, gender, teaching experience and type of school

\begin{tabular}{|c|l|l|c|c|c|c|}
\hline $\begin{array}{c}\text { Name } \\
\text { (pseudonym) }\end{array}$ & Age & Gender & $\begin{array}{c}\text { Qualifi- } \\
\text { cation }\end{array}$ & $\begin{array}{c}\text { Years in } \\
\text { Teach- } \\
\text { ing }\end{array}$ & $\begin{array}{c}\text { Years } \\
\text { working } \\
\text { as } \\
\text { Principal }\end{array}$ & Type of school \\
\hline Tamam & 50 & Female & $\begin{array}{c}\text { MA } \\
\text { Education }\end{array}$ & 25 & 17 & $\begin{array}{c}\text { Elementary mixed } \\
\text { Arab (Christian } \\
\text { Muslim) Low } \\
\text { socio-economic } \\
\text { cluster } \\
526 \text { students }\end{array}$ \\
\hline
\end{tabular}




\begin{tabular}{|c|c|c|c|c|c|c|}
\hline Mohammed & 61 & Male & $\begin{array}{l}\text { PhD } \\
\text { History }\end{array}$ & 23 & 13 & $\begin{array}{l}\text { Elementary mixed } \\
\text { Arab (Christian } \\
\text { Muslim) Low- } \\
\text { middle socio- } \\
\text { economic cluster } \\
621 \text { students } \\
\end{array}$ \\
\hline Nassir & 53 & Male & $\begin{array}{l}\text { MA Public } \\
\text { Managem } \\
\text { ent }\end{array}$ & 21 & 8 & $\begin{array}{l}\text { Junior-High school } \\
\text { mixed Arab } \\
\text { (Christian Muslim) } \\
\text { Low socio- } \\
\text { economic cluster } \\
\text { 1,022 students }\end{array}$ \\
\hline Samir & 50 & Male & BA History & 29 & 7 & $\begin{array}{c}\text { Arab Muslim } \\
\text { junior-high school } \\
\text { Low socio- } \\
\text { economic cluster } \\
826 \text { students } \\
\end{array}$ \\
\hline Nashid & 51 & Male & $\begin{array}{c}\text { MA } \\
\text { Science }\end{array}$ & 25 & 12 & $\begin{array}{c}\text { Mixed Arab } \\
\text { (Christian Muslim) } \\
\text { Middle socio- } \\
\text { economic cluster } \\
527 \text { students } \\
\end{array}$ \\
\hline Yakov & 58 & Male & $\begin{array}{c}\text { PhD } \\
\text { Sociology }\end{array}$ & 22 & 14 & $\begin{array}{c}\text { Jewish only } \\
\text { Junior-High school } \\
\text { High socio- } \\
\text { economic cluster } \\
1,023 \text { students }\end{array}$ \\
\hline Tamar & 51 & Female & $\begin{array}{l}\text { M.Sc. } \\
\text { Mathe- } \\
\text { matics }\end{array}$ & 16 & 8 & $\begin{array}{l}\text { Jewish only } \\
\text { Junior-High school } \\
\text { Middle socio- } \\
\text { economic cluster } \\
468 \text { students } \\
\end{array}$ \\
\hline Rena & 62 & Female & $\begin{array}{c}\text { MA } \\
\text { Jewish } \\
\text { studies }\end{array}$ & 23 & 12 & $\begin{array}{c}\text { Jewish only } \\
\text { elementary school. } \\
\text { Low socio- } \\
\text { economic cluster } \\
674 \text { students } \\
\end{array}$ \\
\hline Shosh & 48 & Female & $\begin{array}{c}\text { MA } \\
\text { Education }\end{array}$ & 19 & 13 & $\begin{array}{c}\text { Jewish mixed } \\
\text { ethnic elementary } \\
\text { school including } \\
\text { Arabs } \\
591 \text { students } \\
\end{array}$ \\
\hline Anat & 60 & Female & $\begin{array}{c}\text { BA } \\
\text { Hebrew } \\
\text { language }\end{array}$ & 21 & 12 & $\begin{array}{l}\text { Jewish only } \\
\text { Middle school } \\
\text { Middle socio- } \\
\text { economic cluster } \\
480 \text { students }\end{array}$ \\
\hline
\end{tabular}

Respondents' average age was 54.4 (ranging from 48 to 62); most had more than 10 years of management experience. There was equal representation for both genders and almost equal representation for elementary and junior-high schools. All principals had academic degrees. The average size of the 
participating schools' populations was approximately 675 students (ranging from 468 to 1,023 students).

As the study is based on a small sample from a specific group of school principals, there are obvious limitations in applying the findings to other social and educational arenas.

\section{Data Analysis}

Interview protocols were transcribed in Arabic for Arab principals and Hebrew for Jewish principals and underwent the four stages of analysis suggested by Marshall and Rossman (2012): "organizing the data," "generating categories, themes and patterns," "testing any emergent hypothesis," and "searching for alternative explanations." I employed this analysis to identify central themes in the data, searching for recurrent perceptions of SJ ideology, personal trajectories, experiences and critical life incidents, and personal attitudes relating to the issue of SJ. In addition, I traced descriptions of individual and school collective actions to reduce injustice. These units of information were then coded, reduced, and connected to form different categories collected into central themes that would help to answer the research questions. Coding was guided by the principles of "comparative analysis" (Strauss \& Corbin, 1998), including comparison of any coded element in terms of emergent categories and sub-categories. Structured analysis and peer review enhanced trustworthiness and reliability (Marshall \& Rossman, 2012). Use of a systematic data collection procedure contributes to the credibility and authenticity of the data.

Since this was a small sample from a specific group of participants, this limits generalization of the findings to other social contexts. The reader is invited to judge the applicability of the findings and conclusions to other similar circumstances.

\section{Findings}

Analysis of the findings from the interviews revealed four main categories around which the central themes of the study were consolidated in line with the research questions and level of analysis:

1. Principals' perception of SJ policy;

2. "The school has its own melody that needs total listening";

3. School policy promoting SJ: "Concentrating resources around the weakened child"; and

4. SJ at the level of the school's pedagogic processes: "Surround them with circles of support." 
These four levels are suggested by Theoharis (2009). The following description of the emergent themes includes citations from the interviews. Names of the interviewees are fictive.

\section{Principals' Perceptions of SJ Policy}

The Jewish nation has been occupied with nation building for the past 65 years and has planned many of its education policies to reinforce the Jewish national state and identity (Arar, 2012). The establishment of a national-cultural identity for Palestinian Arab students was seen as a potential threat to these aspirations, and this attitude is reflected in the almost complete absence of the Palestinian Arab narrative in government-assigned education programs in the Arab education system (Al-Haj, 2005). A policy of alienation, separation, and control is also expressed in the differential allocation of resources to the two education systems (Mazawi, 2003). Education budgets given to Arab local governments are $35 \%$ less than those given to Jewish local governments (BenDavid \& Bleikh, 2013). Outputs of the Arab education system in the international standard PISA exam were on average 116 points less than Jewish education system achievements (Arlosoroff, 2014).

The findings show that the majority of the principals perceive Israeli Ministry of Education policies to reduce gaps as purely declarative (Garratt \& Forrester, 2012). A female principal of a Jewish school, serving a lower socioeconomic cluster mixed ethnic population, succinctly expressed this viewpoint:

The Ministry of Education talks about equity as a slogan. Travel to the Bedouin and see all the garbage that the state discards there. I have Arab students who do not pay education fees and then they do not receive the food allocations, I have to give school dinners to Jewish students and leave them gaping, they leave the responsibility to me, and I have to continually hear complaints that my area is problematic. As the principal, I have to cope with this guilt together with my teachers. (Shoshi)

I heard similar complaints about the lack of investment in reducing gaps by a female Jewish principal:

I come here and there is no food, a third of the children here live on welfare. When we contact welfare, what does it help? (Rena).

The Israeli education system has moved stubbornly to a standardized system, leaving weak populations such as Arabs and peripheries untreated (Gibton, 2011). As noted by Rizvi and Lingard (2010), the vernacularization of national policy cannot be ignored when we try to understand how the school leader's perceptions and actions connect and operate within their local context, as can be seen from the words of an Arab principal who manages a school serving 1,022 students from a deprived community: 
The Arabs are an underprivileged minority in comparison to the Jewish majority. Discrimination appears in economic and social dimensions, in living conditions, physical welfare, in the death rate, the rate of disease and life expectation....This situation undoubtedly influences the shaping of the [Arab] community's order of preference, delaying its choice of education since the local government lacks educational resources...

Government policy and the school context, including the type of school community, the stability of their lives, the economic abilities of the parents, and the students' academic profiles, are all factors that impact on the principal's activities to achieve SJ in the school. The woman principal of a Jewish middle class junior-high school explained how this made it difficult to close gaps:

The politics that has created inequality is cruel; our job is to extricate the children from the cycle of poverty, caused by the state-builders and those who control the resources. (Anat)

Similarly, an Arab elementary school principal in one of the lowest socioeconomic clusters illustrated how government policy increases the gaps between students:

In Israel, Arabs are second-class citizens, and often the state sees them as the enemy that should be fought against, or as a back yard that should be hidden. At the level of policy, we begin from a state of inadequacy, receive less budgets, and are controlled by government clerks considered "experts in Arab matters" who assign learning contents that are totally divorced from our national narrative.....Nevertheless, we are expected to educate for active and relevant citizenship. (Samir)

In contrast to principals of Jewish schools, Arab principals cope with an additional difficulty when implementing government policies in the school, since the disparity between overt and covert government policy affects their daily work.

Government education policies, the unequal distribution of financial resources, and government reforms that impose accountability and place emphasis on academic achievements while ignoring social discourse make the need for SJ discourse ever more acute (Stevenson, 2007). I therefore tried to understand how SJ is expressed in their schools.

\section{"The School Has Its Own Melody That Needs Total Listening"}

The principals' perception of SJ, including giving value to diversity, equal access, and equity, affects educational policy and practice in the schools (Scanlan, 2012). The principals told us about the sources of their perceptions of SJ and how they had been influenced by their life experiences and personal development. For example, a female Jewish principal explained:

A principal brings their whole personal and public lives to their job: the home where they grew up, and the society in which they live. I was born in 
Morocco; my family was blessed with ten children. You can imagine what it is like to share a piece of bread with nine other children.... I was a few months old when I immigrated to Israel; we sat and studied in an immigrant camp. The great turning point in my life was when I became deputy-principal....I tried to liberate the school from its selective approach, but when I didn't manage to do so; I needed to attain the principalship. I relate to the difficulty of parents to pay their contributions, [for me] there is a place for each child...the school has its own melody that requires total listening. (Anat)

The principal Anat illustrated how her personal history influenced her perception of SJ. Similarly the female Jewish principal Shoshi felt that diversity and difference in Israeli society dictated the current need for SJ in the school. Yet, her version of SJ was rooted in her Jewish faith:

The first goal is to reinforce affinity to Judaism, to reduce learning gaps, and to contain all the students, allowing room for difference...we have Israeli-born children, new immigrants including Ethiopians, oriental-origin Jews, and a whole range of cultural backgrounds, and even Arabs who cooperated with the Israelis and were brought here from Gaza, so that it is not simple to provide a place for diversity.

Shoshi's words emphasize that her national and ethnic consciousness actually play a central role in her perception of a commitment to advance SJ in the school. The Arab male principal Nasser applies his perception of SJ to his students' social learning:

$S J$ requires a belief in the students and their abilities and necessitates that we succeed in influencing them and their future. I would never confront a child with the test of being sent home, we embrace them all here. I come from a very difficult background and I try to educate them to undergo change from a very similar background.

The Arab male principal Samir explained his application of his perception of $\mathrm{SJ}$ :

[it includes] humility, listening, a large and compassionate heart. Compassion is the key that opens all doors that people encounter and if the door is open it is very easy to enter the house. Listening in my opinion is an art and not a characteristic, I believe that listening also includes knowing how to speak... listening is knowing how to solve things.

The principals' belief in SJ directs their daily activity in the school, as Rena, a Jewish school principal in a low socio-economic district in the center of Israel, noted:

You educate with everything that you do and say. I believe in allowing everyone to discover their selves.... fight against this notion of a production line.... think its important to provide a response to differences between the students, to provide a place for emotion, a place for Judaism, 
to remember the fallen soldiers....I think it's important to develop critical thinking.

The principal Shoshi also included national awareness in education for SJ:

Education is how you want your state to look, our leaders are not exactly suitable models for imitation... it is my role to educate a generation that will respect ethics and morals and Zionist values.

Shoshi's perception contrasts with the perception of Tamar (another Jewish female principal):

I believe in getting the best out of people and when you give to people in a non-aggressive manner, they aspire to give back in return; SJ is giving a place to diversity. Each student is a different project ... this is unreserved giving.

The Arab principal Nasser gave his own national nuance to his vision of SJ, as did his Jewish colleagues: "The Arab student should graduate with two certificates, academic tools and Arab national values."

Despite the nationalist tone that is a substantial part of the Jewish school ethos and to a lesser extent of the Arab school ethos, most of the principals agreed that implementation of the principles of SJ should enable each child to realize their potential, and that this required the application of humanist values such as listening, giving and concern, in order to improve access to education. Muhammed related to the ethics of care and concern:

When I come close to the child and ask whether he was cold on Saturday, and he tells me that he froze to death, and tells me that his blanket is so thin showing me its size with his fingers. Then I tell the child "let's go and get a cup of tea and you can hold it; that will be your blanket". I foster their sense of belonging, allowing them to have genuine corrective experiences, access, concern and care from a loving grandfather.

The personal story of the female Jewish principal Anat explained how turning points in her career contributed to her awareness of the need for care, concern, and giving:

I have six children in different ways, I have two biological children of my own; I have Nurit aged 30 from Ethiopia whom I adopted when she was two years old. Today she is a social worker with a second academic degree and lives above my apartment .... she is one of the gifts I received .....I also adopted Dima aged 26, he is studying economics and business management, the girls were legally adopted, but Dima is a foster child, although it's as if he were our own. He is one of the Chernobyl children, born with one hand because his mother suffered radiation... his mother chose drugs and gave him up and we try to fill him with warmth and love ...so I'm sure you understand what SJ means for me.

It is clear that the principals' concepts of SJ are strongly influenced by their personal life stories, and national and social contexts. Their perceptions of 
SJ influence the shaping of school policy and the establishment of educational and social processes in the school (Abu-Saad, 2008; Arar, 2012).

\section{"Concentrating Resources Around the Weakened Child"}

School leadership can construct an educational vision focusing on SJ and develop a community committed to the implementation of this vision. This is expressed in the school culture, leadership style and the learning-teaching discourse (Arar, 2014b; Brooks et al., 2007; Scanlan, 2012).

The vision of the Jewish principal Tamar expresses her desire to provide equal opportunity for each student, equipping them with educational resources and values, and encouraging pluralistic attitudes:

We try to promote equal access, we serve areas of underprivileged populations; we have a policy to collect contributions and sponsors in order to equalize resources between weaker and stronger students....I make sure they hear a concert once every two weeks and expose them to things they would not otherwise know ...there is a secular population here that I also try to expose to the subject of Judaism.

Contrastingly, the Jewish principal Shoshi indicated that educational dialog should unconditionally support national values:

There was a human rights activity - it was an organization that wanted to speak against enlistment to the army ... as a Jewish principal, I think it is incorrect to bring such an organization to sit on a panel that debates before the students ... although there should be room for all, I say that because enlistment into the army is obligatory.

The Jewish principal Anat expressed her vision in terms of providing constructive criticism, to enhance self-recognition and self-empowerment:

I think it important to enable personal growth, to allow the child to develop self-awareness and self-capacity, to give them tools, to teach them how to work to attain goals...junior high school should focus on helping them to decide what sort of people they will become, their personality, their selfrecognition, of course this is all done through their learning.

The principal Anat encourages a culture of collective learning and participation to promote teachers' and students' development and empowerment through educational discourse (Scanlan, 2012).

Nasser leads his school through emotional containment, encouraging personal empowerment to create a space in which students can develop collective values of citizenship, by exposing them to diversity.

Yet, the Jewish principal Rena also emphasizes the role of the school in preparing students to defend their homeland: 
I use the army as a unifying code for their experiences. It is very important that they take several units for their matriculation and experience success, it is important that they do not desert the army. Affinity with national discourse constitutes a part of the access process and shaping of the collective experience.

The Arab principal Tamam described an educational journey that she experienced in the school together with her staff, when she was required to provide a personal model:

One of our girls had a difficult accident after which her legs remained paralyzed, limiting her movement until she had a wheelchair. The school is not accessible for children with physical disabilities. The school together with her parents went to the local government to ask that the school be made accessible for her disabilities. I ensured that this would be done by enlisting all possible resources.

We have seen here how the implementation of SJ may include the use of various social and national attitudes within the daily discourse and reality of the school (Arar, 2014a). As will be seen in the next theme, the principals each chose their own contents and strategies to express their sense of mission and to establish their vision of principles of $\mathrm{SJ}$ in the school.

\section{"Surround Them with Circles of Support"}

This theme relates to the principals' daily work for the establishment of SJ. This necessitates undermining the dominant social reality that perpetuates social gaps (Campbell, Gold, \& Lunt, 2003; Scanlan, 2012; Moller \& Vedoy, 2014).

Rena manages a high school for students with learning difficulties, most of whom do not take matriculation exams. She feels that certain values to which she is committed motivate and guide her management:

I have made special plans together with Mako and the Technion institute, including teaching automated carpentry. Some of my students have not taken matriculation exams, but using recycled materials, we made soaps and face creams.

Nasser also directs school activities to empower the students and provide them with a sense of success and self-confidence:

We have a special matriculation program called "Recycling." It was built by one of our teachers out of concern. This stream functions modestly, learning about sustainability, constructing practical things, learning how to repair a button on jeans, how to knit, build constructions from milk cartons, constructing their ideal room. They produce an exhibition that parents and a wide range of other people visit. 
Rena promotes confrontational encounters to improve familiarity between different parts of the society, enabling students to meet with those both similar and different from them, through experiential learning:

The students all run from the town of Shaar Yishuv to Hod Hasharon, it's a two day journey, they get to know the country through their legs, meet other types of young people, some with difficulties, religious youth. I tell the students that I have a son who is homosexual, talk about being "gayfriendly".

Tamar has initiated dialog between staff members in the school, bringing them together to work as a team and raising their consciousness concerning social and professional responsibility. This agenda that Tamar tries to promote helps to construct collective capability and a school learning community that strive to improve the students' reality, through a culture of activity oriented to moral social discourse (Scanlon, 2012).

Similarly, Rena tries to integrate education for the recognition of diversity and $\mathrm{SJ}$ in an active relationship between the school and the school's neighborhood community as part of a democratic system (Starratt, 2002; Theoharis, 2009). She explained:

One of the high points of our activities is the Israel Journey, it gives them a sense of common pain...they receive lectures on the depth of social gaps. It is important that they should learn to respect the "other." There are religious children here with skullcaps, there are other children from a traditional culture, and there are many children who have left the religious sector and come here and taken off their skullcaps.

Educational leadership oriented towards SJ becomes empowered by the presentation of personal example (Arar, 2014b; Bogotch, 2002; Moller \& Vedoy, 2014; Scanlan, 2012). Examples of the use of visible personal models were given by the principal, Tamam:

I always do visible acts, I bring books from home and distribute them to the children, I and the teachers collect clothes and distribute them to children in need. They are part of my home; it's a visible act of personal example.

In conclusion, the testimony presented under this theme shows that personal values, personal development, and personal empowerment are all aims that the SJ-oriented principal attempts to encourage in his or her students, teaching them personal skills and tools and working in the community through participatory processes (Brooks et al., 2007; Moller \& Vedoy, 2014).

\section{Discussion and Conclusion}

The research aimed to clarify perceptions of principals in the Jewish and Arab education systems in Israel concerning the concept of SJ as reflected in 
government policies, school policies, and daily practices. The findings indicate that Neo-liberal government policies mean that schools are forced to cope with an imposed agenda of competitiveness and accountability (Garratt \& Forster, 2012; Gibton, 2011). This discourse ignores the needs of marginal populations and even widens the large gaps in education inputs and outputs between central and peripheral areas of Israel and between the state's majority and minority populations (Arar, 2012; Diem \& Boske, 2012; Gibton, 2011).

The principals indicated that in both national and local government policy and practice, principles of SJ are enunciated at the declarative level, but there is no supported field activity to reduce social and educational gaps with corrective programs or budgets (Arar, 2012; Jabareen \& Agbaria, 2010). While principals in the Jewish schools suggested various strategies to help weaker students overcome difficulties, they did not relate to the need to improve the status of the Arab education system, which exists on the margins of the Jewish education system (Arar \& Abu-Asbah, 2013). Nevertheless some of the principals try as the Arab principal Nasser noted to "swim against the stream" and to establish an empowering discourse of concern, raising collective consciousness concerning the existence of gaps and the need to work to achieve equity (Berkovich, 2014; Scanlan, 2012). They act independently outside government policy enactment and try to build a consciousness that will alter the existing reality (Oplatka \& Arar, 2014).

The findings support the claim of Brooks and Miles (2006) that SJ leaders must "develop a heightened and critical awareness of oppression, exclusion, and marginalization" (p. 5), recognizing and analyzing how institutional power arrangements and practices favor some groups over the others (Diem \& Boske, 2012).

All the interviewed school principals had their own perception of their role in implementing SJ education (Bogotch \& Shields, 2014). Most of Jewish principals perceived that the promotion of SJ involved strengthening Jewish students' national identity and patriotism (Campbell et al., 2003). For most of them, the value of national identity is aligned with the value of SJ as seen in previous research findings (Levy, 2005; Yona \& Shenhav, 2005).

Thus too, an Arab principal explained that he "aims to strengthen Arab students' national identity through dialog on the Arab village, and civic identity, facilitating empowerment through workshops for self-expression." (Nasser)

Nashed (another Arab principal) saw his role as implementing a sociopolitical discourse: "I see the school as a place that prepares students for life, based on the student's personal abilities. I am motivated by values for example: equal opportunities, respect.... see my job as an agent for change, producing a new enabling reality."

Identifying these needs increases the principal's commitment to "collect resources for the weakened student" (Nino, 2014; North, 2008; Theoharis, 2009). 
We see that these principals work hard to bridge the deficiencies caused by concentrated lack of resources (Stevenson, 2007), while principals from both main national groups, Jews, and Arabs, try to educate their youth to patriotic national values. This politically enlisted education reflects a historical conflict and an unstable security reality (Lindsey \& Lindsey, 2011). Some principals even felt committed to encourage national military service as a value as part of their role in educating the younger generation (Yona \& Shenhav 2005) although this message of "national unity" excluded certain groups of students and ignored the value of diversity (Jean-Marie et al., 2009; McNae \& Morrison, 2014).

Nevertheless, the findings also indicate that the principals believe their role is to enable all children from diverse racial, cultural, and ethnic backgrounds to achieve excellence. They see this as the basic element of leadership for SJ (Furman \& Shields, 2005; Mansfield, 2013; Theoharis \& Brooks, 2013), working to decrease the achievement gap; providing necessary resources for disadvantaged students (Garratt \& Forrester, 2012; Theoharis, 2009; Walker, 2006); reforming, aligning, and expanding curricula to meet the needs of particular students with special needs (Adams \& Copeland, 2005). Most of the school principals indicated that SJ leaders should identify and undo oppressive and unjust practices that inhibit all students' achievements (Brooks et al., 2007; Jean-Marie et al., 2009), including those from racially, linguistically and economically diverse backgrounds, especially for children from marginalized groups (Bogotch \& Shields, 2014; Nino, 2014).

We witnessed both Jewish and Arab school principals serving weak communities, attempting to structure their schools to ensure that students learn in heterogeneous, inclusive classrooms in order to confront and attempt to ameliorate the unjust and even 'oppressive' disparities in educational opportunities and outcomes between students from different religions, ethnic groups, and social classes (Boske \& Diem, 2012; Dantley \& Tillman, 2010).

It seems that the principals formed their vision of $S J$ in education due to significant trajectories in their life histories, and these experiences increased their awareness of the role of the educational leader in establishing change in society (Theoharis \& Brooks, 2013). Yet they all implement a similar vision of equal access to education through their sensitivity and respect for diversity (Scanlan, 2012; Jean-Marie et al., 2009). They employ their pedagogy to empower both teachers and students individually and collectively and to alter the existing status of inequality. They encourage participation and a democratic regime in the schools and help students to attain optimal functioning for their future integration in a democratic, pluralistic society (Starratt, 2002; Nino, 2014).

Leaders for SJ are described in terms of inclusive leadership, promoting just distribution of the national capital, and tolerance for others' beliefs and culture (Diem \& Boske, 2012; Lindsey \& Lindsey, 2011). In practice, this kind of leader is expected, among other things, to advocate for inclusion, allow every student access to resources, and acknowledge the claims of historically marginalized groups (Ryan, 2007; Garratt \& Forrester, 2012). 
This comparative study may contribute to the understanding of ways in which enlightened educators in a society dominated by inequitable practices can overcome political and cultural barriers and increase the potential for equity and $\mathrm{SJ}$, in this case in Arab and Jewish schools in Israel. Activities to promote SJ in schools are essential to ensure mutual enrichment between diverse groups in a multicultural state, and educational leaders therefore play a crucial role. The study's contribution stems from its ability to clarify difficulties encountered in the promulgation of SJ in a multicultural reality, split by political conflicts and sometimes racism. During principal training courses, there should be attempts to increase awareness of the managerial cohort to the challenges of diversity and the need to ameliorate the effects of socio-economic gaps through education. They should be provided with knowledge concerning discrepancies in access to education for weaker populations and the potential of education to alter sociopolitical inequalities by personally and collectively empowering underprivileged populations

The rise in numbers of diasporas of diverse cultures, ideologies, and faiths, especially due to the inter-ethnic wars of the last few years, makes it highly significant to understand how educational leadership is perceived and informed in different cultural, social and belief systems. By problematizing 'difference' and pointing to multiple shifts of meaning and their subsequent implications and consequences (Derrida, 1976), we can perhaps extend our understanding of $\mathrm{SJ}$ in diverse cultural arenas.

\section{References}

Abu-Baker, K. (2008). Welfare, modernity and tradition: Palestinian women in Israel cope with changes in their life settings. In A. Manaa, \& R. Gara (Eds.), The Arab society book 2 (pp. 359-384). Jerusalem: Van Leer Institute and Kibbutz Meuhad Publications. [Hebrew].

Abu-Saad, I. (2008). Present absent: The Arab school curriculum in Israel as a tool for de-educating indigenous Palestinians. Holy Land Studies, 7(1), 1743.

Adams, J. Jr. \& Copeland, M. (2005). When learning counts: Rethinking licenses for school leaders, Seattle, WA: Center for Reinventing Public Education.

Al-Haj, M. (2005). National ethos, multicultural education, and the new history textbooks in Israel, Curriculum Inquiry 35(1): 47-71.

Association for Civil Rights in Israel (2011). Social and economic rights in Israel, 2011. Retrieved from http://www.acri.org.il/en/2011/05/14/social-andeconomic-rights-in-israel-2011/

Arlosoroff, Meirav (10.03.2014). An Arab receives 60\% less quality of life than a Jew. The Marker. Retrieved from: http://www.themarker.com/ news/1.2265899 [Hebrew] 
Arar, K. \& Abu-Asbah, K. (2013). Not just location: Attitudes and functioning of Arab local education administrators in Israel. International Journal of Educational Management, 27(1), 54 - 73.

Arar, K. (2012). "Israeli education policy since 1948 and the state of Arab education in Israel. Italian Journal of Sociology of Education. 1, 113-145.

Arar, K (2014a). Discourse of equity and social justice in Muslim high school in Israel, in: F. Salili \& R. Hossain (Eds.), Growing up between two Cultures: Issues and problems of Muslim children (pp.187-206). Charlotte, NC: Information Age Publishing.

Arar, K. (2014b). Vice-Principals in Arab schools in Israel: An era of reform. International Journal of Educational Management, 28(1), 96 - 113.

Arar, K., \& Abu-Rabia-Queder, S. (2011). Turning points in the lives of two pioneering female school leaders in the Arab society in Israel. Journal of Gender and Education, 1, 1-15.

Arar, K., Shapira, T., Azaiza, F, \& Hertz-Lazrowitz, R. (2013). Arab women in management and leadership. New York, NY: Palgrave Macmillan.

Avney Rosha Institute (2009). School principal training in Israel. Jerusalem: Avney Rosha Institute Publications. Retrieved from: http://www.avneyrosha.org.il/Train/DocLib/\%D7\%94\%D7\%9B\%D7\%A9\% D7\%A8\%D7\%94\%20-

Ayers, W., Quin, T., \& Stovall, D. (Eds.) (2009). Handbook of social justice in education. New York, NY: Routledge.

Balas, N. \& Adler, H. (2009). Inequality in the education system: Israel 2009 Status quo. Discussion paper. Jerusalem, Israel: Taub Centre.

Ben-David, D. (2014). A status picture of the state - Flowcharts on the subject of society and economy in Israel. Jerusalem, Israel: Taub Center.

Ben-David, D., \& Bleikh, H. (2013) Poverty and inequality over time: In Israel and the OECD. In Taub Center, State of the Nation Report - Society, Economy and Policy 2013. Jerusalem, Israel: Taub Center.

Berkovich, I. (2014). A socio-logical framework of social justice leadership in education. Journal of Educational Administration, 52(3), 282-309.

Blankstein, A, \&Houston, P. (Eds.) (2011). Leadership for social justice and democracy in our school. Thousands Oaks, CA: Corwin Press.

Bogotch, I. E. (2002). Educational leadership and social justice: Practice into theory. Journal of School Leadership, 12, 138-156.

Bogotch, I., \& Shields, C.M. (2014). Introduction: Do promises for social justice trump paradigms of educational leadership and social (in)justice. In Ira Bogotch \& Carolyn M. Shields (Eds.)International handbook of educational leadership and social (in) justice.(pp.1-12). Dordrecht, The Netherlands: Springer. 
Brooks, J. S., \& Miles, M. (2006). From scientific management to social justice . . . and back again? Pedagogical shifts in the study and practice of educational leadership. International Electronic Journal for Leadership in Learning, 10, Article 21. Retrieved from http://www.ucalgary.ca/iejll

Brooks, J. S., Jean-Marie, G., Normore, A. H., \& Hodgins, D. W. (2007). Distributed leadership for social justice: Exploring how influence and equity are stretched over an urban high school. Journal of School Leadership, 17, 378-408.

Campbell, C., Gold, A., \& Lunt, I. (2003). Articulating leadership values in action: Conversations with school leaders. International Journal of Leadership in Education, 6(3), 203- 221.

Central Bureau of Statistics (April 14 ${ }^{\text {th }}, 2013$ ). $65^{\text {th }}$ Independence Day - More than 8 million residents in the State of Israel. Press Release. Retrieved from http://www.cbs.gov.il/www/hodaot2013n/11 13 097e.pdf [Hebrew]

Creswell, J. W. (2007). Research design: Qualitative, quantitative and mixedmethods approaches $\left(3^{\text {rd }}\right.$ ed.). Thousand Oaks, CA: Sage.

Cubillo, L., \& Brown, M. (2003). Women into educational leadership and management: International differences? Journal of Educational Administration, 41(3), 278-29.

Dantley, M. E., \& Tillman, L. C. (2010). Social justice and moral transformative leadership. In C. Marshall \& M. Oliva (Eds.), Leadership for social justice (2nd ed., pp. 19-34). Boston, MA: Allyn \& Bacon.

Derrida, J. (1976). Of grammatology. Baltimore, MD: John Hopkins University Press.

Diab, K., \& Mi'ari, M. (2007). Collective identity and readiness for social relations with Jews among Palestinian Arab students at the David Yellin Teacher Training College in Israel. Intercultural Education,18(5), 427-444.

Diem, S., \& Boske, C. (2012). Introduction - Advancing leadership for social justice in a global world. In C. Boske \& S. Diem (Eds.), Global leadership for social justice: Taking it from the field to practice (pp. 6-18). London. UK: Emerald Publishing.

Furman, G. (2012). Social justice leadership as praxis: Developing capacities through preparation programs. Educational Administration Quarterly, 40(1), 47-76.

Furman, G. C., \& Shields, C. M. (2005). How can educational leaders promote and support social justice and democratic community in schools? In W. A. Firestone \& C. Riehl (Eds.). A new agenda for research in educational leadership (pp. 119-137). New York, NY: Teachers College Press.

Gara, R. (2013). Arab society in Israel $6^{\text {th }}$ book. Jerusalem, Israel: Van Leer Institute. [Hebrew] 
Garratt, D., \& Forrester, G. (2012). Educational policy unraveled. London, UK: Continuum.

Ghanem, A., \& Rouhana, N. (2001). Citizenship and the parliamentary politics of minorities in an ethnic state: The Palestinian citizens in Israel. Nationalism and Ethnic Politics, 7(1), 66-86.

Gibton, D. (2011). Post-2000 law-based educational governance in Israel: From equality to diversity. Educational Management, Administration and Leadership, 39(4), 434- 454.

Golan-Agnon, D. (2006) Separate but not equal: Discrimination against Palestinian Arab students in Israel, American Behavioral Scientist 49: 1075-84.

Hofstede, G. (2001). Culture consequences: Comparing values, behaviours, institutions, and organizations across nations (2nd ed.). London, UK: Sage Publications.

Jabareen, Y,, \& Agbaria, A. (2010). Education on hold: Government policy and civil society initiatives to advance Arab education in Israel. Nazareth, Israel: Dirasat, Arab Center for Law and Policy.

Jean-Marie, G., Normore, A.H., \& Brooks, J. (2009). Leadership for social justice: Preparing 21st century school leaders for new social order. Journal of Research on Leadership Education, 4(1), 1-31.

Levy, G. (2005). From subjects to citizens: On educational reforms and the demarcation of the "Israeli-Arabs." Citizenship Studies, 9(3), 271-291.

Lindsey, R., \& Lindsey, D. (2011). Social justice: Focusing on assets to overcome barriers. In A. Blankstein \& P. Houston (Eds.). Leadership for social justice and democracy in our schools (pp. 25- 44). Thousand Oaks, CA: Corwin Press.

Mansfield, K. C. (2013). I love these girls - I was these girls": Women leading for social justice in a single-sex public school. Journal of School Leadership, 23(4), 640- 663.

Marshall, C., \& Rossman, G. (2012). Designing qualitative research (2nd ed.). Thousand Oaks, CA.: Sage Publications.

Mazawi, A. (2003). Concentration of disadvantage in resources and accessibility to matriculation certificates in Arab and Jewish settlements in Israel. In Y. Dror, D. Nevo \& R. Shapira (Eds.). Changes in education - Outlines for education in Israel in the 20th century (pp. 56-57). Tel Aviv, Israel: Ramot Publications. [Hebrew].

McNae, R., \& Morrison, M., (2014). School leadership for social justice in Aotearoa, New Zealand. Paper Presented at CCEAM conference, Brunswick University, Canada, June 6 - 10.

Moller, J., \& Vedoy, G. (2014). Norway- leadership for social justice: Educating students as active citizens in a democratic society, In C. Day, \& D. Gurr 
(Eds.). Leading schools successfully- stories from the field (pp. 163-173). London: Routledge.

Nakhleh, K. (1979). Palestinian dilemma: Nationalist consciousness and university education in Israel. Detroit, MI: Association of Arab and American Graduates.

Nino, J. M. (2014). Latino for social justice: A case study, Paper Presented at CCEAM conference, Brunswick University, Canada, June 6-10.

Noddings, N. (2003). Caring: A feminine approach to morals and education $\left(2^{\text {nd }}\right.$ ed.) Berkeley, CA: University of California Press.

North, C. (2008). What is all this talk about "social justice"? Mapping the terrain of education's latest catchphrase. Teachers College Record, 110(6), 11821206.

Oplatka, I., \& Arar, K. (2014). An oriental interpretation of leadership for social justice: A speculative perspective. Paper Presented at CCEAM conference, Brunswick University, Canada, June 6-10.

Rizvi, F., \& Lingard, B. (2010). Globalizing education policy. Oxon, UK: Routledge.

Rodriguez, G. M., \& Bauman, J. (2005). Leading for social justice: A journey of inquiry and reflective practice. Journal of School Leadership, 16(2), 126141.

Ryan, J. (2007). Dialogue, identity, and inclusion: Administrators as mediators in diverse school contexts. Journal of School Leadership, 17, 340-370.

Sanders-Lawson, E. R., Smith-Campbell, S., \& Benham, M. K. P. (2009). Wholistic visioning for social justice: Black women theorizing practice. In C. Marshall \& M. Oliva (Eds.). Leadership for social justice: Making revolutions in education ( $2^{\text {nd }}$ ed.) (pp. 74-99). New York, NY: Allyn \& Bacon.

Sagie, A., Kantor, J., Elizur, D., \& Barhoum, M. I. (2005). A cross-cultural investigation of personal values:The Israeli-Palestinian case. Problems and Perspectives in Management, 2, 148-156.

Sbirsky, S., \& Degan-Bouzaglo, N. (2009) Discrimination, inequality and lax control, status quo of Israeli education. Tel Aviv, Israel: The Edva Center.

Scanlan, M. (2012). A learning architecture: How school leaders can design for learning social justice. Educational Administration Quarterly, 49(2), 348391.

Shaviv, M., Weinstein, N., Stone, A., \& Bodam, A. (2013). Pluralism and equal access for Arabs in Higher education system in Israel. Jerusalem, Israel: The Israeli Council for Higher Education \& Budgeting. (Hebrew).

Shoho, A. (Ed.) (2006). Preparing leaders for social justice: Overcoming pathologies of silence. Journal of Educational Administration, 44(3), 196208. 
Smooha, S. (2002). The model of ethnic democracy: Israel as a Jewish and democratic state. Nation and Nationalism, 8(4), 475-503.

Starratt, R. J. (2002). Community as curriculum. In K. Leithwood (Ed.). Second international handbook of educational leadership and administration (pp. 321-348). Dordrecht, The Netherlands: Kluwer Academic Publishers.

Stevenson, H. P. (2007). A case study in leading schools for social justice: When morals and markets collide. Journal of Educational Administration, 45(6), 769-781.

Strauss, A. L., \& Corbin, J. (1998). Basics of qualitative research: Techniques and procedures for developing grounded theory $\left(2^{\text {nd }}\right.$ ed.). Thousand Oaks, CA: Sage.

Theoharis, G. (2009). The school leaders our children deserve: Seven keys to equity, social justice and school reform. New York, NY: Teachers College Press.

Theoharis, G., \& Brooks, J. S. (2013). What every principal needs to know to create equitable and excellent schools. New York, NY: Teacher College Press.

Thomas, G. (2011). How to do your case study. London, UK: Sage Publication.

Walker, J. (2006). Principals and counselors working for social justice: A complementary leadership team. Educational Administration Quarterly, 43(2), 221- 258.

Yiftachel, O., \& Ghanem, A. (2004). Understanding "ethnocratic" regimes: The politics of seizing contested territories. Political Geography, 23(6), 647676.

Yona, Y., \& Shenhav, Y. (2005). What is multiculturalism. Tel-Aviv, Israel: Babel (Hebrew).

\section{Author Contact}

Khalid Husny Arar: khalidarr@gmail.com

The Center for Academic Studies, Rehov HaYotzrim 2, Or Yehuda, Israel 